\title{
Airway Obstruction and Patchy Parenchymal Infiltrations Related to Tear Gas Exposure
}

\author{
Göz Yaşartıcı Gaz Maruziyetine Bağlı Hava Yolu Obstrüksiyonu ve Bilateral Yamalı Parankimal \\ İnfiltrasyonlar
}

\section{Nilüfer AYKAÇ \\ (i) 0000-0003-1407-8258}

Gayrettepe Florence Nightingale Hospital Chest Diseases Clinic, İstanbul, Turkey

\section{Corresponding Author Sorumlu Yazar \\ Nilüfer AYKAÇ niluferkongar@gmail.com}

Received / Geliş Tarihi : 11.06.2020 Accepted / Kabul Tarihi : 13.08.2020 Available Online /

Çevrimiçi Yayın Tarihi : 25.08.2020

\begin{abstract}
A 50 year old nonsmoker female patient with respiratory complaints including phlegm and effort-related dyspnea admitted to the hospital. Anamnesis pointed out neither occupational nor hobby-related exposures. However, she mentioned several intense tear gas exposures, and describe dyspnea and wheezing right after these exposures. Computed tomography of the lung showed patchy areas of consolidation and ground glass opacity. Pulmonary function tests revealed an FEV1/FVC ratio of $67 \%$. Chlorobenzylidene malononitrile (CS) gas related pulmonary involvement was evident due to the lack of lesions on previous radiographs, improvement of her complaints and respiratory function test, and regression of the parenchymal lesions after ceasing the exposure. This case is presented to emphasize the importance of taking detailed anamnesis of the patient and to demonstrate the negative impacts of physical and social environment on human health, and more specifically to suggest that the riot control gases used are not as harmless as believed.

Keywords: Toxic gas inhalation; inhalation injury; tear gas.
\end{abstract}

ÖZ

Elli yaşında hiç sigara içmemiş kadın hasta, balgam ve eforla artan nefes darlığı gibi solunum yakınmaları ile hastaneye başvurdu. Anamnezde bu semptomlara yol açabilecek ne mesleki ne de hobileri ile ilişkili bir özellik yoktu. Bununla birlikte, birkaç kez yoğun göz yaşartıcı gaza maruz kaldığından bahsetti ve bu maruziyetlerden hemen sonra nefes darlığı ve hırıltı tarif etti. Bilgisayarlı tomografisinde akciğerde iki taraflı periferik dağılımlı yamalı infiltrasyonları ve buzlu cam opasiteleri mevcuttu. Solunum fonksiyon testinde FEV1/FVC oranı \%67 idi. Daha önceki radyografilerde lezyon olmaması, maruziyet kesildikten sonra yakınmalarında ve solunum fonksiyon testinde düzelme ve parankim lezyonlarında gerileme olması chlorobenzylidene malononitrile (CS) gazı maruziyetine bağlı pulmoner tutulumun kanıtlarıydı. Bu olgu özellikle hastadan ayrıntılı anamnez almanın öneminin altını çizmek, çevresel ve sosyal ortamların insan sağlığı üzerine olumsuz etkisini göstermek ve kullanılan gazların düşünüldüğü kadar masum olmadığını vurgulamak için sunulmuştur.

Anahtar kelimeler: Toksik gaz inhalasyonu; inhalasyon hasarı; göz yaşartıcı gaz.

\section{INTRODUCTION}

Aerosols used as riot control agents mainly include chlorobenzylidene malononitrile (CS), chorobenzoxazepine $(\mathrm{CN})$ and oleorensincapsicum. These agents are taken via inhalation, skin contact and digestive system. They may cause rhinorrhea, sneeze, cough, dyspnea, bronchoconstriction and lung edema (1). Due to the lack of postexposure studies, adverse health effects of tear gas are not well documented. This report is about a case with airway obstruction and bilateral patchy parenchymal infiltrations due to tear gas exposure. 


\section{CASE REPORT}

A 50 year old nonsmoker female with respiratory complaints including phlegm and effort related dyspnea with no prior history of similar problems (including asthma) admitted to the hospital. Anamnesis pointed out neither occupational nor hobby-related exposures. However she mentioned several intense tear gas exposures 14, 13 and 11 days ago. Right after these exposures, the patient described dyspnea and wheezing. She also complained about effort-related dyspnea and dry cough, sometimes in periods of about 10 days.

The patient's medical history includes left partial mastectomy caused by invasive ductal carcinoma, lymph node dissection, radiotherapy and chemotherapy two years ago. The patient was stable and taking no medical care for breast cancer. She also had a history of escitalopram use for two years.

Examination results were as follows: vital respiratory rate was $18 / \mathrm{min}, \mathrm{SaO}_{2}$ was $97 \%$ in room air, expiratory wheezing and widespread rhonchi were present. Routine laboratory tests, including white blood cell count and differential red blood cell count, liver and renal functions, and serum C-reactive protein levels were normal.

Computed tomography (CT) of the lung showed patchy areas of consolidation and ground glass opacity with a predominantly peripheral distribution on upper lobe of right lung and lower lobe on left lung (Figure 1).

Pulmonary function tests revealed FEV1 as $70 \%$ and FEV1/FVC ratio of $67 \%$. The patient, with preliminary diagnosis of toxic gas inhalation injury was given maintenance therapy with an inhaled corticosteroid twice daily and, when needed, an inhaled short-acting beta2 sympathomimetic agent and macrolide antibiotic. She was also informed about the potential adverse effects of tear gas exposure. One month later, tear gas exposures was ceased and the patient was asymptomatic, the CT scan and pulmonary function tests were almost normal (FEV1\%87, FEV1/FVC ratio of \%85).

Informed consent was obtained from patient who participated in this case.

\section{DISCUSSION}

Numerous public protests took place among various countries during 2013. Local police forces utilized riot control agents, mainly tear gas, excessively and systematically. Due to the nature of events, the probability of being exposed to high levels of tear gas, more than once, was increased among participants. Aforementioned case had a history of multiple tear gas exposures.
Respiratory problems caused by the exposure to CS include burning sensation in the throat, cough, wheezing, dyspnea and laryngospasm. CS exposure basically leads to irritable effect on mucous membranes. Common cause of death is due to asphyxia and circulatory failure (1). Animal experiments proved that high levels of CS exposure may cause chemical pneumonitis and fatal pulmonary edema (2). Severe pneumonitis that required the use of oxygen, steroids and antibiotics, was observed on an infant after excessive exposure to CS (3). Irritant induced asthma was reported when a gas canister exploded 2-3 meters away from a healthy female (4). In case of environmental ventilation is limited, exposure to high levels of CS caused death in 12-48 hours among rabbits and guinea pigs. Cause of death in animal experiments is lung damage (5).

Moreover, in postmortem examination of 10 cases that resulted in death after the use of riot control agents support the experimental research findings; Toprak et al. (6) detected edema accompanied by intra-alveolar hemorrhage in the posterior-basal areas of the lung, diffuse superficial acute necrosis in the mucosa, acute inflammatory cell infiltration, epithelial desquamation, bronchopneumonia, hyaline membranes and "asthmatic changes" in alveoli. In the long-term follow-up of 93 cases exposed to similar agents, Arbak et al. (7) showed that the rate of $\%$ predicted maximal mid expiratory flow rate (MMFR) in people exposed to gas with no smoking history is significantly less in comparison to the mean FEV1/FVC and $\%$ predicted MMFR in people exposed to gas that are tobacco users (7). Finally, in the examination of 86 patients exposed to gas where Ilgaz et al. (8) reported that the respiratory function test findings of people exposed to gas were more adversely affected if they were exposed to gas or used tobacco in the indoor environment.

In the Turkish and English literature, there is no patient with lung parenchymal pathology similar to our case after exposure to tear gases. In our opinion, the most important reason for this is that the research on patients exposed to similar agents are based on questionnaire inquiry and/or respiratory function test. Therefore, our case is the first stimulating example to detect lung parenchymal pathologies caused by tear gases.

With no contrary evidence, the airway spasm findings and infiltrative images seen in lung parenchyma were associated with the exposure to excessive tear gas (CS).

To sum it up, experimental studies which demonstrated death and lung damage, and real life findings about the exposure to tear gases suggests that they may not be as
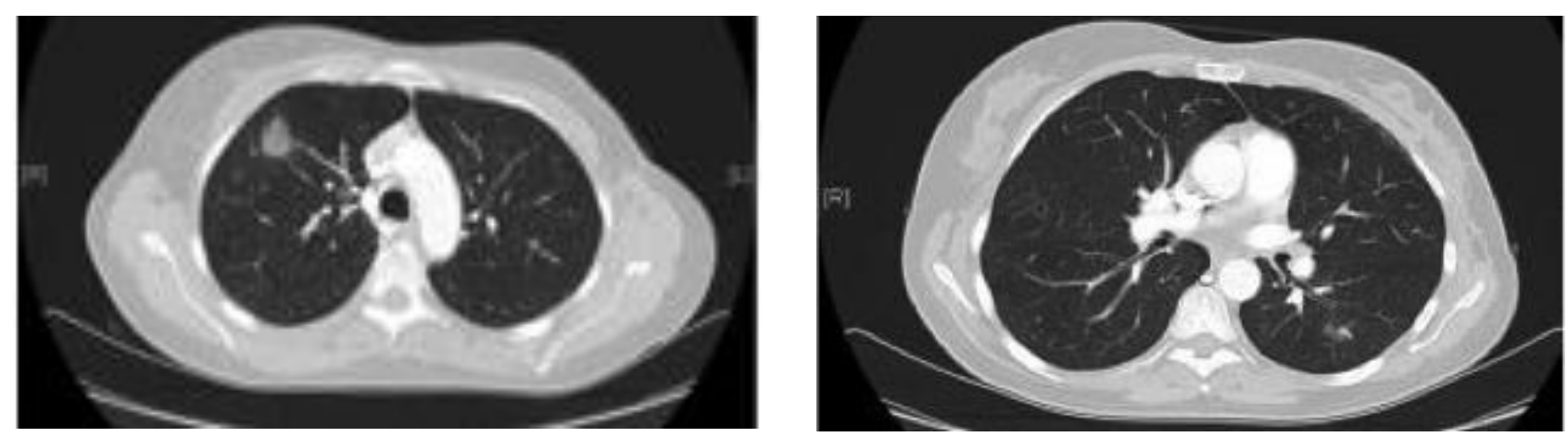

Figure 1. Computed thorax tomography (patchy areas of consolidation and ground glass opacity) 
innocent as it is generally believed. Mid and long term health effects of exposure to these should be (re)evaluated more seriously.

\section{REFERENCES}

1. Dimitroglou Y, Rachiotis G, Hadjichristodoulou C. Exposure to the riot control agent $\mathrm{CS}$ and potential health effects: a systematic review of the evidence. Int J Environ Res Public Health. 2015;12(2):1397-411.

2. Worthington E, Nee PA. CS exposure--clinical effects and management. J Accid Emerg Med. 1999:16(3):168-70.

3. Park S, Giammona ST. Toxic effects of tear gas on an infant following prolonged exposure. Am J Dis Child. 1972;123(3):245-6.

4. Hu H, Fine J, Epstein P, Kelsey K, Reynolds P, Walker
B. Tear gas--harassing agent or toxic chemical weapon? JAMA. 1989;262(5):660-3.

5. Rothenberg C, Achanta S, Svendsen ER, Jordt SE. Tear gas: an epidemiological and mechanistic reassessment. Ann N Y Acad Sci. 2016;1378(1):96-107.

6. Toprak S, Ersoy G, Hart J, Clevestig P. The pathology of lethal exposure to the Riot Control Agents: towards a forensics-based methodology for determining misuse. J Forensic Leg Med. 2015;29:36-42.

7. Arbak P, Başer İ, Kumbasar ÖO, Ülger F, Kılıçaslan Z, Evyapan F. Long term effects of tear gases on respiratory system: analysis of 93 cases. Sci World J. 2014;2014:9636638.

8. Ilgaz A, Uyanusta FÇK, Arbak P, Müezzinoğlu A, Çiftçi UT, Akpınar S, et al. Extensive exposure to tear gases in Ankara. Turk Thorac J. 2019;20(2):108-13. 